\title{
Jegets stemme og digtets kilder (Valéry)
}

JAN HOLMGAARD

His voice was not unkind. It was not human, personal at all. It was just cold, implacable, like written or printed words.

William Faulkner

Paul Valéry formulerer sin poetik gennem sin digtning. Men han skaber også altid det, vi kan kalde en poetisk form, i sine essays om digtningen. Valérys digtning udspringer af en overbevisning om, at dens mulighed befinder sig i en paradoksal hæven sig over de konventionelle betydninger. Denne indsigt medfører, og må medføre en meta-kritisk dimension i skabelsen af digtets fysiske form. Digtet må bøje sig indover sig selv, gøre sig selv til digtets emne, for at kunne opnå noget andet, noget endnu ikke defineret. Hvis denne ikke-definerede dimension konstituerer digtets egentlige væsen, er det også de teoretiske implikationers opgave at deltage i den aktivitet digtet frembyder, hvilket indebærer, at disse teorier må formuleres i poetiske termer. Heri ligger en uoversættelighed gemt, en uoversættelighed som vi aldrig kan ophæve, men blot undersøge i dens sammenhæng ved at følge Valérys egen strategi et stykke af vejen. Man finder da hurtigt ud af, at hans holdning til poesien er intimt sammenvævet med forsøget på at skrive et jeg ind i denne ikke-definerbare skrift, som udgør digtet. Forestillingen om en tiltale eller en stemme skulle gøre formidlingen af det uoversættelige muligt. 
Men hvordan lader dette sig gøre? Hvordan danner jeget sig i en diskurs, der selv-opløsende arbejder sig væk fra betydningens bestandige orden. Det er denne problemstilling vi her vil opholde os ved.

I de indledende linjer til den ofte citerede ottende strofe i Le cimetière marin står der:

O pour moi seul, á moi seul, en moi-même,

Auprès d'un coeur, aux sources du poèmes,

Entre le vide et l'événément pur

[O for mig selv, til mig selv, i mig selv,

nær et hjerte, ved digtets kilder,

mellem tomheden og den rene hændelse] ${ }^{1}$

Invokationen vækker jeget, men synliggør samtidig hvordan den talende og den tiltalte narcissistisk falder sammen. Præcist som Narcissus-myten forudsætter invokationen en oprindelig kløvning eller distancering for overhovedet at kunne opstå. Men det er ikke en tematisering vi kan bekræfte eller tale med om, da invokationen falder tilbage på digtet selv, ",ved digtets kilder". Digt og jeg flettes sammen for at gives en umulig "plads" i strofens tredje linje, hvor det hviler i en dobbelt tomhed. Bogstaveligt kan vi betragte en "ydre" tomhed som omgiver og modsiger den rene hændelse. Men digtet og jegets egentlige plads er mellem "entre" - disse instanser. De optræder ikke som et sammenflettende element, dvs. i et både-og mønster af tomhed og hændelse, men i et hverken-eller, dvs. i en fundamental negering af en given position. Digtet og jegets plads er hverken tomhed eller hændelse, men noget andet, en dæmoni.eller „indre" tomhed, hvis kraft kun kan kanaliseres gennem forskydningen af et dialektisk forløb.

Derfor må såvel digtet som dets teori formuleres udfra et stående og pågående paradoks hvor igennem ethvert begrebspar forskydes ind i en lakune af ubestemmelighed. Hvis vi, som Blanchot, konstaterer at Valérys poetik er opbygget gennem en bestandig opstilling af modsætninger, ${ }^{3}$ er det samtidig helt centralt at fastslå, at disse har et dybere indhold, nemlig at synliggøre det umuliges tomhed. Når også paradokset brister optræ- 
der den lakune som ikke blot er digtets kilde, men også, i flertal, dets "kilder" eller "oprindelser", for denne lakune formuleres ved at digtet bestandigt vender tilbage til det, fortaber sig i det, for blot igen fremkomme og styrte sig i dets uendelighed.

Jeget og digtet, den menneskelige dimension og det sproglige materiale, sammenfalder i blotlæggelsen af denne „indre” tomhed hos Valéry. Dette bliver særlig tydeligt, hvis vi bevæger os over til en nøglepassage i Valérys essay Poésie et pensée abstraite. Med et pædagogisk anlagt billede udfolder han der sin teori om det poetiske pendul - „le pendule poétique" - som oscillerer mellem son og sens, digtets lydlige dimension og digtets betydning. Metaforen synes at være taget direkte fra Mallarmé og dennes drøm om pendulets „dobbelte fuldbyrdelse”, dvs. forestillingen om et digts fremkomst som ren musik, men helt på skriftens betingelser, i det musikken og bogstaverne danner en helstøbt genre, "un genre entier". ${ }^{4}$ Den asymmetriske implikation af denne helstøbthed eller enhed ${ }^{5}$ gøres udtrykkelig hos Valéry, idet han konstaterer, at den selv-opfyldte idealitet som definerer musikkens univers ikke genfindes $\mathrm{i}$ ordenes betydningsladede verden. Han skriver:

Rien de pur; mais un mélange d'excitations auditives et psychiques parfaitement incohérents. Chaque mot est un assemblage instantané d'un son et d'un sens, qui n'ont point de rapport entre eux.

[Ingenting rent; kun en blanding af fuldstændigt inkohærente auditive og psykiske tilstande. Ethvert ord er en umiddelbar sammenføjning af son og sens, af tone og betydning, som ikke har nogen forbindelse med hinanden] (I, p. 1328)

Det virkelige interessante ved Valérys pendul er ikke blot den modsætning den udspringer af, men også måden hvorpå han beskriver dets bevægelse. 6 Dets son og sens ledsages af nogle centrale synonymer, således at pendulet oscillerer „Entre la Voix et la Pensée, entre la Pensée et la Voix, entre la Présence et l'Absence. [Mellem Stemmen og Tanken, mellem Tanken og Stemmen, mellem Nærvær og Fravær]" (I, p. 1333). „Stemmen" og „tanken" peger på et metonymisk jeg. Spørgsmålet om digtets 
eventuelle enhed, dets bevægelse mellem son og sens, forbindes med den metafysiske åbenbaring af det menneskelige jegs storhed. Metonymien effektuerer en klassisk dualisme, et perspektiv som gøres endnu tydligere, når vi i Cantiques Spirituels finder den poetiske enhed fremstillet som „une alliance aussi intime que celle du corps avec l'âme [et forbund ligeså intimt som det mellem kroppen og sjælen]" (I, p. 457).

Samtidig er Valérys pendul indfattet i kunstens klassiske hierarki, det historisk arrangerede begrebsskema mellem form og indhold. Når Valéry taler om stemmen, sigter han nemlig primært til den poetiske form, ,les caractères sensible du langage, et le son, le rythme, les accents, le timbre, le mouvement - en un mot, la Voix en action [sprogets sanselige karakter, og tonen, rytmen, accentueringerne, klangen, bevægelsen - med et ord, den handlende Stemme]" (I, p. 1332). Stemmens nærvær udgør således den ene side af pendulbevægelsen, mens den anden defineres af en "productions de choses absentes [frembringelse af fraværende ting]": Dette fravær er intet mindre end digtets indhold, „le sens d'un discours [diskursens betydning]" (I, p. 1333).

Hvordan vi end vælger at betragte denne orden er det umuligt at se bort fra den indsigt, at digt og subjekt (det metonymiske jeg) flettes sammen i den entitet Valéry forsøger at etablere med sin metafor. Denne figur danner dermed en metafysisk cirkularitet, der ogșå kan beskrives som en ',cercle en abyme", som er Derridas betegnelse for denne type selvudbredende model mellem væren og værket.7 I nærværende tilfælde henviser vi med „afgrund" til det faktum, at ordenens totalitetsfordring stilles overfor sprogets retoriske dimension. Det er en dimension som sætter os på sporet af paradoksets væsen.

Oscilleringens bevægelse mellem nærværet og fraværets kategorier sigter mod at sammenføre dem i, hvad Jean Hytier i sit standardværk La poétique de Valéry, kalder „Une union mystique".8 Og mystisk er den sandt at sige eftersom den metafor der holder afvigelsen sammen i en bevægelse, nemlig billedet af pendulet, aldrig kan forklare hvordan de to poler kan bringes til at sammenfalde uden at metaforen underminerer sig selv. Det poetiske pendul forudsætter i stedet en forskel, som det samtidig skal 
skabe illusionen om at overbinde. Det suggesterer et helstøbt billede, hvis betydning dekonstruerer sig selv.

En mindre radikal tolkning er givetvis - med Hytier - forsøgsvis at pege på en samtidighed af uafhængighed og uopløselighed mellem de to instanser. Hytier citerer også Valéry, som i Tel Quel taler om "une harmonie indéfinissable [en ubestemmelig harmoni]" (II, p. 637). Men en sådan ubestemmelighed hinsides den dialektiske orden er kun mulig, hvis vi her accepterer metaforens metaforicitet, dvs. dens helt igennem retoriske præg, hinsides hvilken vi vil finde tomheden og ikke begrebsligheden. Hytiers tese accepterer velvilligt illusionen om pendulets dobbelt fuldbyrdelse, men har sværere ved at gøre rede for dens iboende modsætning, der fortæller os, at dens bevægelse kun er mulig så længe den udspringer fra en tidslighed baseret på en forskel. Den helhed og samtidighed som forespejles i denne figur kræver en blindhed af os, som ikke forråder metaforens indre modsigelse.

Om dette er Valéry næppe uvidende. Umiddelbart efter at have vakt pendulbevægelsen til live i Poésie et pensée abstraite konstaterer han:

Il résulte de cette analyse que la valeur d'un poème réside dans l'indissolubilité du son et du sens. Or, c'est la un de condition qui paraît exiger l'impossible. Il n'y a aucun rapport entre le son et le sens d'un mot [Resultatet af denne analyse er, at et digts værdi ligger i uopløseligheden mellem tone og betydning. Men denne tilstand viser sig at kræve det umulige. Der er ingen forbindelse mellem lyden og betydningen af et ord] (I, p. 1333)

Det er digterens opgave at skabe „la sensation de l'union [fornemmelsen af enhed]", hvis virkning Valéry beskriver som vidunderlig - merveilleux. Pendulmetaforen er selv et eksempel på denne vidunderlige illusoriske effekt, som holder sammen på sproget og skænker digtet dets „,værdi“.

Denne illusion, skrevet ovenpå umuligheden, kompliceres af pendulets metonymiske aspekt. Det kan nemlig betragtes som en del af en allegorisk struktur, hvor den dualistiske figuration "Voix" og "Pensée" udsiger noget andet end det pendulet udsiger, noget fraværende og uudsigeligt, som kun synliggøres ved 
ikke at være der. Vi retter her blikket mod selve metonymiens funktion som trope. Dens fraværende dimension synes at modsvare den form for jeg, som vi i konventionel forstand forsøger at finde i teksten, såsom en subjektiv storhed, der må negeres for at iklædes tropens skikkelse. Stemme og tanke vil få os til at se bort fra teksten, det eneste nærværende i en naiv og derfor højst bogstavelig forstand. Formens nærvær er således noget andet, den er fraværet af en konkret stemme, som Valéry efterlyser ved at gøre den synonym med ordet. Hans metonymi vidner om stemmen og talens hierarkiske placering, som udgangspunkt for sprogets tilstedeværelse og mulighed for kommunikation. Men figurationen i dette, med dens allegoriske implikation, peger samtidig på den negation, som skaber stemmens form. Enhver fordring på en klar tale, opfyldt af den talende og verdens referentialitet, brister overfor sprogets retoriske kraft. Netop derfor kan vi også konstatere, at denne kraft både opløser og indstifter stemmens værdi i den poetiske tekst. Den metonymiske stemmes forbindelse til en metafysisk begrebsorden er lige så figurativ som dens opdukken i Valérys poetik. Tropen erstatter et fravær eller læses som en udfyldelse af en tomhed, som synes uudholdeligt med sit brud på helheden og forsoningen mellem det man kan kalde respektivt subjektet og digtets stemme.

Valéry afslutter Poésie et pensée abstraite med at definere stemmen som selve digtets fundament. Udfra dagligsproget er det digterens opgave at frembringe

[...]une Voix pure, idéale, capable de communiquer sans faiblesses, sans effort apparent, sans faute, contre l'oreille et sans rompre la sphère instantanée de l'univers poétique, une idée de quelque moi merveilleusement supérieur à Moi.

[en ren, ideel stemme, i stand til at kommunikere uden svaghed, uden synligt besvær, uden fejl, mod øret og uden at bryde det poetiske univers' umiddelbare sfære, en idé om et slags jeg, Jeget forunderlig overlegent] (I, p. 1339)

Digtets transcendering af et „moi" er lige så „vidunderlig" som illusionen om ordets paradoksale enhed. ${ }^{9}$ Men hvad er genstand for denne magi? 
Den stemme Valéry taler om svarer ikke til den tale, hvormed verden præsenteres, hvor spørgsmålet om hvordan noget siges forsvinder for at lade hvad der siges fremtræde. En sådan kommunikabilitet medfører for Valéry en fornægtelse af sproget, dets død. Digtets styrke ligger i dets evne til at ophæve en sådan transparens. Valéry siger således: „le poéme ne meurt pas pour avoir vécu [digtet dør ikke af at have levet]" (I, p. 1331). Den sanselige, nærværende og levende stemme i Valérys poetik kan kun være teksten hinsides det menneskelige jegs stemme, en tekst hvori gennem jeget trancenderes til et figurativt aftryk, der unddrager sig identifikation udenfor det transcendente. Stemmen besidder ikke længere sit fonocentriske grundlag. Det er opløst i tekst, og er dermed også, i overensstemmelse med Valérys egen formulering om det overlegne jeg, mere stemme end Stemmen selv. I en ofte citeret passage fra Tel Quel peger Valéry på hvordan begæret efter en menneskelig stemme - la voix humaine - gennem læseakten erstattes af „un oeil rapide, avide, libre sur une page [det hurtige og begærlige øje, der bevæger sig frit over siden]" (II, p. 549). Dette indebærer på ingen måde en bekræftigelse af den stumme læseakt. I stedet må vi tale om en forskydning af stemmens hierarkiske position.

Det skal ikke forstås således, at digtet dermed giver stemmen materialitet. Snarere drejer det sig om, at denne stemme mister sin symbolske dimension. Dens drøm om enheden mellem signifiant og signifié er opløst i den allegoriske linearitet, som er tekstens egen. I troperne og figurernes spil genfindes kun tomheden, der iscenesættes gennem den ubestemthed disse figurationer er skrevet med.

Men det er tydeligt, at Valérys metonymi er til for at opretholde det individuelt motiverede ord uden hvilket sproget ville miste sin legitimitet. Dets vibrerende tale er for Valéry også digtets ideelle grund. I forelæsningen Première lecon du cours de poétique finder vi en passage, hvor Valéry kaster lys over denne stemme og dens betydning for digtet:

Un poème sur le papier n'est rien qu'une écriture soumise à tout ce qu'on peut faire d'une écriture. Mais parmi toutes ses possibilités, il en est une, et une seule, qui place enfin ce texte dans les conditions où il 
prendra force et forme d'action. Un poème est un discours qui exige et qui entraîne une liasion continuée entre la voix qui est et la voix qui vient et qui doit venir. Et cette voix doit être telle qu'elle s'impose, et qu'elle excite l'état affectif dont le texte soit l'unique expression verbale. Otez la voix et la voix qu'il faut, tout devient arbitraire. Le poème se change en une suite de signes qui ne sont liés que pour être materiellement tracés les uns après les autres.

[Et digt på papir er intet andet end en skrift underkastet alt hvad man kan gøre med en skrift. Men blandt alle dens muligheder er der en, og kun én, der tilsidst placerer denne tekst under betingelser, hvor den får styrke og skaber handling. Et digt er en tale, som kræver og medfører en uafbrudt forbindelse mellem stemmen der er og stemmen der kommer og som bør komme. Og denne stemme bør være én, der gør sig påtrængende, og som vækker den affektive tilstand, hvori teksten gives et unik verbal udtryk. Fjern stemmen og stemmen der behøves: alt bliver tilfældigt. Digtet forandrer sig til en række tegn, der kun er forbundet ved at de rent fysisk udgør et spor, den ene efter den anden.] (I, p. 1349)

Det er påfaldende, hvor nutidig Valéry kan forekomme at være i sit ræsonnement, når han bekræfter tekstualiteten i stemmen, samtidig med at han opfatter stemmens funktion som et forsvar mod ordenes tilfældighed. Den tidslige udstrækning i denne stemmes bevægelse som Valéry tegner konturerne af, peger på den nødvendighed læseakten tildeles i hans poetik. Den stemme "der kommer" er den stemme, som kommer til digtet gennem læseakten, på samme måde som den „bør komme" for at digtet skal få liv - bestandigt og altid nyt i mødet mellem tekst og læser. ${ }^{10}$ Men hvilken er den oprindelige stemme, denne stemme som er?

Selvom vi, i forlængelse af det allerede sagte, indskriver denne stemme i det nærvær som er digtet eller tekstens negativt handlende stemme - "la Voix en action" - kan vi ikke se gennem fingre med det faktum, at stemmen her oppebæres af begrebslogikkens fundament, kopulaer, hvor igennem den metafysisk nærværende stemme antydes, altså den fore-givende, fonocentriske stemmes storhed.

Endnu engang inddrages vi i modsætningen i Valérys poetik. Vi kan nu enten tolke denne stemme som et både-og mønster, hvor stemmen genindstifter digtet i verdens skikkelse, 11 eller så accepterer vi den ubestemmelighed Valérys retorik vækker til live, en 
retorik som truer med at forlægge stemme i en a-positionering helt hinsides det tænkbare. Det "le moi" som antydes gennem stemmens opdukken, denne stemme som er, kan da betragtes i spaltningen mellem den konventionelle og metafysisk farvede betingelse for det dette ord, og den retoriske, figurative handling som i egentlig forstand skaber enhver form for poetisk stemme. Det jeg digtet lover os er et jeg, der er transcenderet af sproget og digtets uendelige nærvær og form; det er den uendelige lingvistiske bevægelse forbundet med et subjektivt aftryk. Dette forudsætter dog en fornyet overvejelse af hvad et subjekt er. Det skriver sig ind i den retoriske diskurs, for dér at fortabes. Ud af denne negation opstår istedet den uendeligt åbne hermeneutiske opgave at bringe det, som nu er tekst, tilbage til dets menneskelige dimension. Dette er det dybere indhold i Valéry tidslige skildring af stemmens nærvær i digtet. Det drejer sig ikke om at lede efter det autentiske Jeg, men om at teksten afgiver de effekter, som på en overgribende måde fremkalder den "stemme " som såvel digtet som læseakten er afhængig af. Opgøret med en metafysisk orden ligger i det faktum, at disse effekter ikke længere tilbyder det underliggende eller "fraværende" svar på livets gåder. Under den figurative struktur er der ingen symbolsk, forenende kraft, men blot den tomhed, som bestandigt peger tilbage på figurationen selv, som en del af digtets gåde.

Denne opfattelse af, at Valérys metafor (pendulet) og hans metonymi (stemmen og tanken) er opstillet som et modværn mod den ubestemmelighed de samtidig er skrevet med, for så vidt at de ikke kan beskytte sig mod denne apori i sproget, kan tydliggøres til et påtrængende mønster, hvis vi vender tilbage til den måde, hvorpå Valéry fremskriver pendulbevægelsen i Poésie et pensée abstraite. Lad mig citere passagen igen: „Mellem Stemmen og Tanken, mellem Tanken og Stemmen, mellem Nærvær og Fravær." Retorisk defineres denne konstruktion som en chiasme, mere præcist i antimetabolens skikkelse (gentagelse i omvendt rækkefølge). Chiasmen kan traditionelt læses som en dialektisk figur med sigte på helhed. Pendulmetaforens overgang i en chiastisk formulering kan ses som en måde at underbygge foreningens forunderlige idé. 
Men chiasmen inverterende bevægelse viser også en interessant diskrepans. I en passage i La dissémination beskriver Derrida den form for chiastisk orden, som „ne mélange pas deux éléments préablablement séparés [bland ikke to elementer sammen, som før var adskilt]”, men „elle renvoie au même qui n'est pas l'identique [det viser tilbage til det samme som ikke er identisk]". ${ }^{12}$ I stedet for krydsningens stræben efter enhed, med dens fordring på begrebsidentitet, holder Derrida fast ved forskellen i chiasmens figur. Enhver "modpol", i form af en inversion, fremviser et brud $\mathrm{i}$ forsøget på at sammenkæde denne pol med den første, som selv er en inversion af den anden. Kort sagt, „,au même qui n'est pas l'identique". Enhver inverteret gentagelse kan kun virke som et supplement til en oprindelig brist på identiteten. ${ }^{13}$

Chiasmen er dermed delagtig i den overordnede retoriske struktur, som baserer sig på det Paul de Man kalder „substitutive reversals", en form for uendelig figurativ kæde af substitutioner hindes den "oprindelige" orden, der ikke findes. ${ }^{14}$ Chiasmen er blot den sidstei en kæde af substitutioner, som fylder i den endelighed som sproget ikke kan tilbyde. Uanset om Valéry griber til metaforen, metonymien eller chiasmen for at realisere en enhed såvel inde i digtet som $\mathrm{i}$ jegets dualitet, er alle disse forsøg også en del af en vedvarende underminering af en given betydningsorden. De optræder i en gentagende bevægelse, hvor de hele tiden støder mod den lakune af ubestemmelighed, som de selv er skrevet med.

Men heri ligger det poetiske sprogs egentlige magi. Det vi nu kan definere som ubestemmelighedens figurationer henleder vores opmærksomhed på såvel den sproglige struktur som det poetiske jegs selv-spaltning og ikke-identiske væsen. Magien optræder når vi ser, at det som forener digtet og jeget, i metaforen, metonymien og den fælles chiastiske skikkelse, er den ubestemmelighedens udsathed, hvormed de faktisk realiseres. Den indre apori som opløser disse entiteter i flygtige figurationer, er også den kraft som formår at føre dem sammen i den skandaløse tilstand, der finder sted „entre le vide et l'événement pur [mellem tomheden og den rene hændelse]", i den tilstand som hverken er 
væren eller intet, men den ubestemmelighed, som også synes at være digtets mangfoldige oprindelse.

Det jeg som skaber sig selv i invokationens øjeblik forudsætter dog ikke kun en ubestemmelighed mellem den talende og den tiltalte, gestaltet i digtets apori. Den forudsætter også en læseakt, der villigt accepterer den ikke-definerende, glitrende placering. Hvis det er således som Valéry siger, at digtet er læsningen af digtet, kan vi blot konstatere, at hans negative poetik måske bygger på det faldne menneskes evige illusion. I et af sine Cahiers skriver Valéry:

Nous ne sommes pas des origines, mais l'illusion de l'être est avec nous. [Vi er ikke oprindelige, men illusionen om at være det findes hos os. $]^{15}$

Det er denne illusion som det er vores opgave blindt at sætte i spil ...

Oversat af Mads Rosendahl Thomsen 


\section{Noter}

1. Paul Valéry, Oeuvres, I \& II, (Bibliothèque de la Pléiade), éd. par J. Hytier, Paris 1957/60, I, p. 149.

2. Jvf. Jacques Derrida, som i "Qual Quelle, Les Source de Valéry", i Marges de la philosophie, Paris 1972, konstaterer at "kilden" ikke kan tematiseres i Valérys forfatterskab, idet kilden - „la source" - ikke har en oprindelig eller bogstavelig betydning. Når vokationen falder tilbage på "digtets kilder", brister muligheden for tematisering (se p. 332). Derrida opholder sig også ved problemet om stemmen og tiltalens narcissisme (pp. 325-363).

3. Maurice Blanchot skriver: „Toute l'oeuvre de Valéry est entraînée vers une contradiction entre les termes de laquelle elle répunge à choisir, qu'elle répunge même à reconnaître précisément pour une contradiction.", i La part du feu, Paris 1949, p. 270.

4. Stéphane Mallarmé, Oeuvres Complète, (Bibliothèque de la Pléiade), texte établi et annoté par H. Mondor et G. Jean-Aubry, Paris 1945, p. 649. 5. Jvf. Suzanne Bernard, Mallarmé et la musique, Paris 1959, p. 35, hvor hun meget træffende peger på hvordan Mallarmés forestilling om musikken opstilles som en „rival” til det poetiske sprog.

6. Nicole Celeyrette-Pietri har i Valéry et le moi, Paris 1979, undersøgt oscilleringens bevægelse hos Valéry i mere generelletermer, og har sat den i forbindelse med Newtons matematiske pendul. Målet er at nå enhedens idé: „Il rassamble les idées de deux positions extrêmes opposées et symétriques, avec passage au zéro de l'équilibre, la notion pure de movement ainsi que celles d'énergie et de réversibilité." (p. 53)

7. Jacques Derrida, La vérité en peinture, Paris 1978, p. 29 f.

8. Jean Hytier, La poétique de Valéry, Paris 1953, p. 311. Hytier har iøvrigt en meget oplysende gennemgang af son-sens problematikken, pp. 8388. Se ligeledes Albert Henrys elegante udlægning i Langage et poésie chez Paul Valéry, Paris 1952, især „Le poète et le langage”, pp. 16-37, hvor han bl.a. taler om Valérys oscillering og dobbelthed som en "transmission harmonique et integrale." (p. 24)

9. Respektivt „merveilleux" og "merveilleusement".

10.Mere specifikt om læseaktens betydning, se W. I. Ince, The Poetic Theory of Paul Valéry, Leiceter 1961, specielt kapitlet „Poetry and the Reader” (pp. 64-94), hvor han især taler om læseakten med hensyntagen til Valérys afvisning af såvel inspirationsmyten som referencen til forfatter i fortolkningsakten. Valérys ideale læser „would share with the poet his lack of illusion regarding the 'truth' of the poem" (p. 94). En læsemåde som yderligere forstærker behovet for en ideal læser i Valéry poetik, finder vi hos Vincent Kaufmann, Le livre et ses Adresses, Paris 1986, pp. 151-182.

11.Jvf. Christine M. Crow, Paul Valéry and the Poetry of Voice, Cambridge 1982. Crow ambition er at inkorporere såvel den metakritiske som den 
åbne livsbekræftende perspektivering i Valérys digtning. De afsluttende sætninger i hendes projekt peger dog uafladeligt på en metafysisk læsemåde. Således kan hun eksempelvis konstatere: „For Valéry, the substance of language must be increased in order to reveal the laws of being outside language." (p. 35, min kursiv). Et mere nyanceret billede af Valérys syn på forholdet mellem jeget og sproget får man hos Hytier, fx p. 74. 12.Jacques Derrida, La dissémination, Paris 1972, p. 145.

13.Som en kontrast til denne dekonstruktion af chiasmen, kan der henvises til Jean-Marc Houperts analyse. Han diskuterer, i bogen Paul Valéry, écriture et la tragique, Paris 1986, den chiastiske struktur hos Valéry som en unificerende figur, hvori gennem oscilleringens ambiguitet bliver en selvtilstrækkelig entitet, der er i stand til at indeslutte enhver modsætning i sin egen form, $\mathrm{fx}$ ", 1 'ordre se lie au désordre, la destruction à la construction, la brisure à l'union, le vague au net et la dissonance à l'harmonie - les mêmes éléments jouant sur les deux tableaux en même temps. C'est ainsi que la scintillation sème sur le poéme une ambiguiité souveraine [...]" (p. 194). Houperts formulering udpeger kraftfuldt nødvendighedens potentiale i Valérys chiastiske figuration, men undlader at iagttage dens egen indre "brisure" hvori gennem eksempelvis det poetiske jeg, som fremskrives metonymisk, skriver sig mod umulighedens grænse.

14.Paul de Man, Allegories of Reading, New Haven and London 1979, p. 113.

15.Paul Valéry, Cahiers 8, Paris 1958, p. 895. 
